Jurnal Kesehatan Masyarakat
http://journal.unnes.ac.id/nju/index.php/kemas

\title{
MALARIA COMMUNITY HEALTH WORKERS ELIMINATING MALARIA IN BANYUMAS REGENCY
}

\author{
Dwi Sarwani $\mathrm{SR}^{1}{ }^{\bowtie}$, Sri Nurlaela ${ }^{1}$, Devi Octaviana ${ }^{1}$, Hari Kusnanto ${ }^{2}$, E Elsa Herdiana $\mathrm{M}^{3}$ \\ ${ }^{1}$ Department of Public Health, Faculty of Health Science, Universitas Jendral Soedirman, Indonesia \\ ${ }^{2}$ Department of Public Health, Faculty of Medicine, Universitas Gadjah Mada, Indonesia \\ ${ }^{3}$ Center for Tropical Medicine and Department of Parasitology, Faculty of Medicine, Universitas Gadjah \\ Mada, Indonesia
}

\begin{tabular}{l} 
Article Info \\
\hline Article History: \\
Submited October 2015 \\
Accepted June 2016 \\
Published July 2016 \\
\hline Keywords: \\
Community Health \\
Workers; knowl- \\
edge; attitudes; skill \\
\hline DOI \\
http://dx.doi.org/10.15294/ \\
kemas.v12i1.4030
\end{tabular}

\begin{abstract}
Banyumas has not reached the elimination of malaria yet. One of the efforts is done by community empowerment by establishing malaria Community Health Workers (CHWs/ JMD). JMD are people who conduct the discovery and medication of malaria in Active Case Detection (ACD). The research aims at describing JMDs attitude and knowledge towards the malaria elimination in Banyumas Regency in 2015. Quantitative research with cross sectional design was performed in the study. There were 15 JMDs spreading across in 7 public health centers/Puskesmas. The results show that most of JMDs were male with primary education background. They are mostly employed and do not join any training within 3 years. The average age of JMDs is 48.4 years old although there are some workers who are over 65 years old. 33.3\% of JMDs are in low-medium categories, and there are $26.7 \%$ JMDs who have negative attitude to malaria. All JMDs have less skill such as not to do home visits as scheduled, not to do periodic reports, not to send blood preparations immediately and unstandardized of the blood preparation.
\end{abstract}

\section{Introduction}

Malaria still becomes a health problem for global community. There are estimated 207 million cases of malaria in 2012 worldwide with the majority of cases $(80 \%)$ occur in Africa, Southeast Asia (13\%) and Eastern Mediterranean (6\%). The data from WHO state that the number of malaria cases is expected to increase from 226 million in 2000 to 244 million in 2005, and then decrease to 207 million in 2012. An estimated of 627,000 malaria deaths happen globally in 2012, with $90 \%$ of deaths occur in Africa, 7\% in Southeast Asia and 3\% in the Eastern Mediterranean. There are estimated 482,000 malaria deaths occur in children under the age of 5 years or $77 \%$ of all deaths.

According to the Report of the Health Research (Riskesdas) in 2013, the incidence of malaria in Indonesia in 2013 is $1.9 \%$. The number is declined as compared to 2007 which is $2.9 \%$ although there are still some provinces with a high Annual Paracite Incidence (API) so that the potential for transmission and outbreaks can occur. The data shows that 17 provinces from 33 provinces have Annual Parasite Incidence or API value $<1$ per 1000 inhabitants, 10 provinces have API score between 1-5 per 1000 populations and 6 provinces have $>5$ per 1000 population. There is even a province with API which has a value of $>50$ per 1000 population (Badan Penelitian dan Pengembangan Kesehatan Kemenses RI, 2013). An estimated 132.8 million people in Indonesia are living in malaria-risking areas. There are about $70.3 \%$ of the areas which are unstable transmission in Indonesia and most of the populations live in those areas of unstable transmission (Elyazar, 2011). 
In order to overcome the problem of malaria, there is a global commitment in the $60^{\text {th }}$ World Health Assembly (WHA) in 2007 on the elimination of malaria for each country. The malaria elimination implementation guidelines have been formulated by WHO in Global Malaria Program. In Indonesia, the Government has issued The Decree of the Minister of Health No. 293 of 2009 on the Elimination of malaria in an effort to support the malaria elimination program. In order to achieve malaria elimination, there are many obstacles encountered including lack of professional health workers and malaria experts, the lack of trained human resources and personnel, lack of community involvement in early detection system for active case detection (ACD) as well as lack funding (Renwarin, 2014).

In Central Java Province, there are five endemic malaria regencies and have history of High Case Incidence (HCI) villages, namely Purworejo, Kebumen, Purbalingga, Banyumas and Jepara regencies. Malaria cases in Banyumas have fluctuated in the last 10 years but tend to decline in 2010. Although the number of cases are dropped in the last 4 years, but the caution still needs to be improved because of malaria cases in Banyumas in 2014 shows that $86 \%$ cases are imported cases and $16 \%$ of cases are indigenous. The spread of malaria cases in Banyumas occur in rural districts which are still classified and far away from the center of government (Purwokerto). Therefore, there are still many forests, yards, and fields around people's settlements (Rejeki, 2014).

The existence of Malaria Health Worker in the Village (Juru Malaria Desa-JMD) serves as a community empowerment effort for the prevention of malaria. JMD is an officer conducting discovery and treatment for Active Case Detection (ACD). They are recruited from the community by the District Health Office together with the community health center (Puskesmas) to work in villages where malaria becomes an endemic. They work under job contract and are paid monthly. The numbers of JMD in Banyumas are 15 people, spreading over in 7 areas of Puskesmas namely Puskesmas I Tambak, Puskesmas I and II Sumpiuh, Puskesmas I Kemranjen, Puskesmas Somagede, Puskesmas Banyumas and Puskesmas Kebasen.
This study aims at describing JMD in order to realize malaria elimination in Banyumas, in terms of knowledge, attitudes and skills.

\section{Method}

This study used cross sectional design to describe the knowledge, attitudes and skills of JMD. The populations of this study were all JMD in Banyumas Regency. The samples were the entire population of the criteria who were willing to participate in the research. All 15 people in population served as the samples in the study. The collection of data was conducted through interviews and observations to determine the knowledge, attitude and skills of JMD. The collected data was then processed and analyzed by univariate analysis. Data variables were presented in tables and graphs. The knowledge aspects which were measured included definition, etiology, transmission, symptoms, diagnosis and treatment. The knowledge and attitude were categorized as high if the total scores were more than the mean plus the standard deviation, the medium category was when the total score was in the range of mean value plus the standard deviation to the mean value minus standard deviation, low category was if the total score was less than the mean minus the standard deviation. The skill of JMD consisted of activities such as home visits, periodic reports submission, blood clots delivery, responsibility for the all the materials, equipment, medicines and preparation of blood. In the preparation of blood, JMD practiced how blood retrieval and preparation for thick and thin bloods. Variables were measured by interview and observation. Observation was conducted to determine whether the procedure preparation of blood had been carried out properly by JMD or not.

\section{Results and Discussion}

Banyumas regency is divided into 27 districts consisting of 331 villages. Geographically, Banyumas Regency is located between $105^{\circ}$ and $109^{\circ} 30$ east longitude and about $7^{\circ} 30$ south latitude. The total area of Banyumas Regency is approximately 1327.60 $\mathrm{km} 2$, equivalent to $132,759.56$ ha. Banyumas regency has 39 community health centers/ Puskesmas. During the period of nearly 


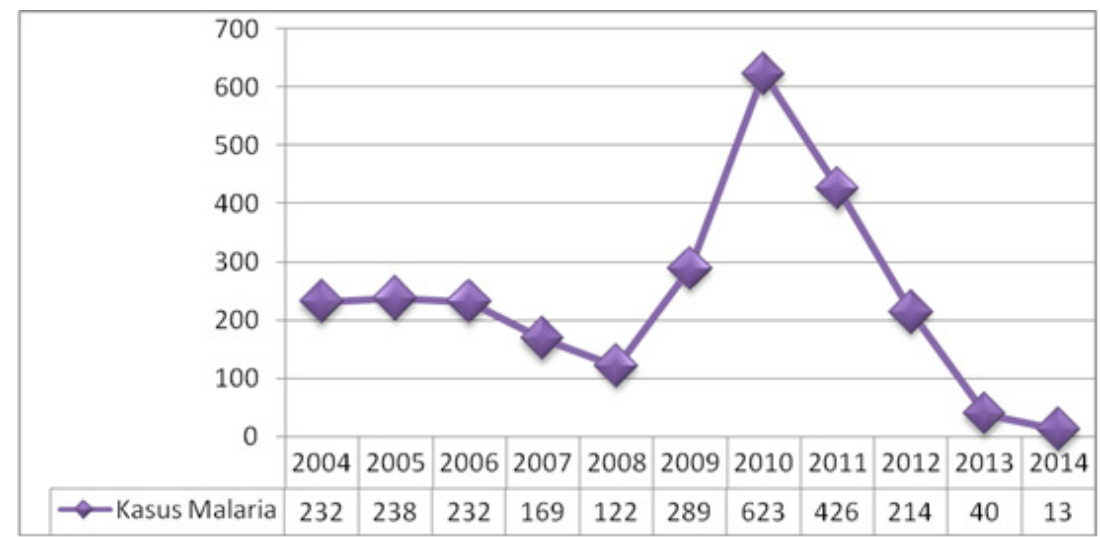

Figure 1. positive trend of malaria cased in Banyumas in $2004-2014$

four years, malaria cases in Banyumas tend to decrease. Here is the case of malaria in Banyumas from 2007-2013.

The highest malaria cases occur in Banyumas Regency in 2010 until 2014 in Puskesmas I Kemranje (91 cases), Puskesmas I Sumpiuh (491 cases), Puskesmas II Sumpiuh (209 cases) and Puskesmas I Tambak (272 cases). The districts that often report the cases of malaria in Banyumas are Tambah district, Sumpiuh district, Kemranjen district and Kebasen district. Kemranjen district, Simpiuh districts and Tambah district are included in malaria endemic districts with the category High Case Incidence (HCI) in Banyumas Regency.

\section{1) The Characteristics of JMD}

JMD in Banyumas Regency are spread across in 7 regions where malaria becomes endemic. Most JMD are male and the average age is 48 year old. Most JMD in Banyumas Regency have primary education background (SD and SMP) and they ahave jobs other than being JMD. The average tenure is 8.8 years and most of them have not received training in the last 3 years.

\section{2) JMD Knowledge}

Normality test result indicates that the knowledge data of JMD is normally distributed. The average score of knowledge is 31,87 with standard deviation of 2.67. Here is the level of knowledge about malaria JMD.

\begin{tabular}{|c|c|c|c|}
\hline No. & Characteristic & Total & Percentage \\
\hline \multirow[t]{8}{*}{1.} & \multicolumn{3}{|l|}{ Puskesmas } \\
\hline & Tambak 1 & 1 & 6,7 \\
\hline & Sumpiuh 1 & 2 & 13,3 \\
\hline & Sumpiuh 2 & 3 & 20,0 \\
\hline & Kemranjen & 4 & 26,7 \\
\hline & Kebasen & 2 & 13,3 \\
\hline & Banyumas & 2 & 13,3 \\
\hline & Somogede & 1 & 6,7 \\
\hline \multirow[t]{3}{*}{2.} & Sex & & \\
\hline & Male & 13 & \\
\hline & Female & 2 & \\
\hline \multirow[t]{4}{*}{3.} & Age & & \\
\hline & Average & 48,4 thn & \\
\hline & Youngest & 36 thn & \\
\hline & Oldest & 65 thn & \\
\hline \multirow[t]{3}{*}{4.} & Education & & \\
\hline & SD/SLTP & 11 & 73,3 \\
\hline & SLTA & 4 & 26,7 \\
\hline \multirow[t]{3}{*}{5.} & Occupation & & \\
\hline & Unemployed & 0 & 0,0 \\
\hline & Employed & 15 & 100,0 \\
\hline \multirow[t]{3}{*}{6.} & Income & & \\
\hline & $\begin{array}{l}\text { High }(\geq \mathrm{Rp} \\
1.100 .000)\end{array}$ & 2 & 13,3 \\
\hline & $\begin{array}{l}\text { Low }(<\mathrm{Rp} \\
1.100 .000)\end{array}$ & 13 & 86,7 \\
\hline \multirow[t]{5}{*}{7.} & JMD tenure & & \\
\hline & Average & & \\
\hline & Minimum & 8,8 years & \\
\hline & Maximum & 1 year & \\
\hline & & 14 years & \\
\hline \multirow[t]{3}{*}{8.} & JMD training & & \\
\hline & already & 1 & 6,7 \\
\hline & not yet & 14 & 93,3 \\
\hline
\end{tabular}




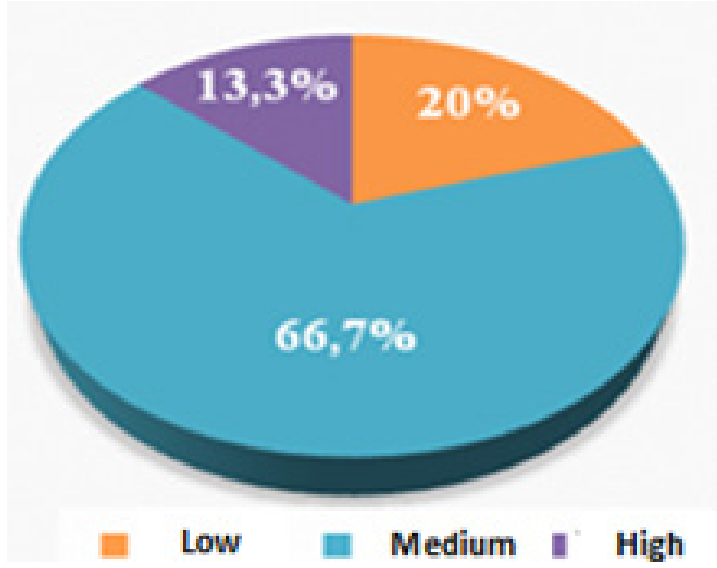

Figure 2. Level of JMD Knowledge About
In general, 33.3\% of JMD in Banyumas have less knowledge about malaria. The aspects that are less understood by JMD between are definition, etiology, transmission and symptoms of malaria.

\section{3) JMD Attitude}

Normality test result shows that the data of attitude is normally distributed. The average score for attitude id 26,40 with standard deviation of 1,99 . JMD attitudes about malaria is presented in the below figure.

Table 2. The Description of JMD Knowledge in Banyumas 2015

\begin{tabular}{|c|c|c|c|}
\hline No & Statement & True $\mathrm{f}(\%)$ & false $\mathrm{f}(\%)$ \\
\hline & Definition of Malaria & & \\
\hline 1 & Malaria is hereditary * & $13(86,7)$ & $2(13,3)$ \\
\hline 2 & Malaria is transmitted by Anopheles & $14(93,3)$ & $1(6,7)$ \\
\hline 3 & Malaria attacks the red blood cells & $13(86,7)$ & $2(13,3)$ \\
\hline 4 & Malaria is not contagious ${ }^{\star}$ & $15(100)$ & $0(0)$ \\
\hline \multirow[t]{2}{*}{5} & Malaria does not cause death ${ }^{\star}$ & $14(93,3)$ & $1(6,7)$ \\
\hline & Etiology of Malaria & & \\
\hline 6 & The cause of malaria is Plasmodium & $13(86,7)$ & $2(13,3)$ \\
\hline 7 & Plasmodium vivax is not the cause of malaria in humans ${ }^{*}$ & $13(86,7)$ & $2(13,3)$ \\
\hline 8 & Plasmodium infects red blood cells & $15(100)$ & $0(0)$ \\
\hline 9 & $\begin{array}{l}\text { Plasmodium falciparum does not cause acute malaria* } \\
\text { Transmission }\end{array}$ & $6(40,0)$ & $9(60,0)$ \\
\hline 10 & Human is the intermediary place of malaria parasite place & $13(86,7)$ & $2(13,3)$ \\
\hline 11 & Malaria is not transmitted through blood donation ${ }^{\star}$ & $9(60,0)$ & $6(40,0)$ \\
\hline 12 & Anopheles does not carry malaria parasite malaria* & $13(86,7)$ & $2(13,3)$ \\
\hline 13 & Malaria is not transmitted to the fetus * & $13(86,7)$ & $2(13,3)$ \\
\hline 14 & $\begin{array}{l}\text { Male Anopheles does not transmit malaria } \\
\text { Symptoms }\end{array}$ & $13(86,7)$ & $2(13,3)$ \\
\hline 15 & Chilling fever is one of the symptoms of malaria & $15(100)$ & $0(0)$ \\
\hline 16 & Malaria symptoms are not typical & $12(80,0)$ & $3(20,0)$ \\
\hline 17 & Patients with malaria may be lack of blood & $12(80,0)$ & $3(20,0)$ \\
\hline 18 & $\begin{array}{l}\text { The main symptoms of malaria are nausea and vomiting * } \\
\text { Diagnosis }\end{array}$ & $4(26,7)$ & $11(73,3)$ \\
\hline 19 & Physical examination malaria shows pale hand & $13(86,7)$ & $2(13,3)$ \\
\hline 20 & The process of drying blood clots can use lights and a hair dryer ${ }^{\star}$ & $8(53,3)$ & $7(46,7)$ \\
\hline 21 & Examination of RDT is only for the outbreaks and remote areas & $12(80,0)$ & $3(20,0)$ \\
\hline \multirow[t]{2}{*}{22} & $\begin{array}{l}\text { Microscopic examination is the formal standard form the examination } \\
\text { of malaria }\end{array}$ & $15(100)$ & $0(0)$ \\
\hline & Treatment & & \\
\hline 23 & Chloroquine is medicine which is not used & $11(73,3)$ & $4(26,7)$ \\
\hline 24 & Vitamin B complex and Vitamin C as supporting medicines & $12(80,0)$ & $3(20,0)$ \\
\hline 25 & The treatment of malaria depends on the parasite types & $12(80,0)$ & $3(20,0)$ \\
\hline 26 & Malaria medicine is changed if patients are not cured & $12(80,0)$ & $3(20,0)$ \\
\hline
\end{tabular}

Source: primary data 


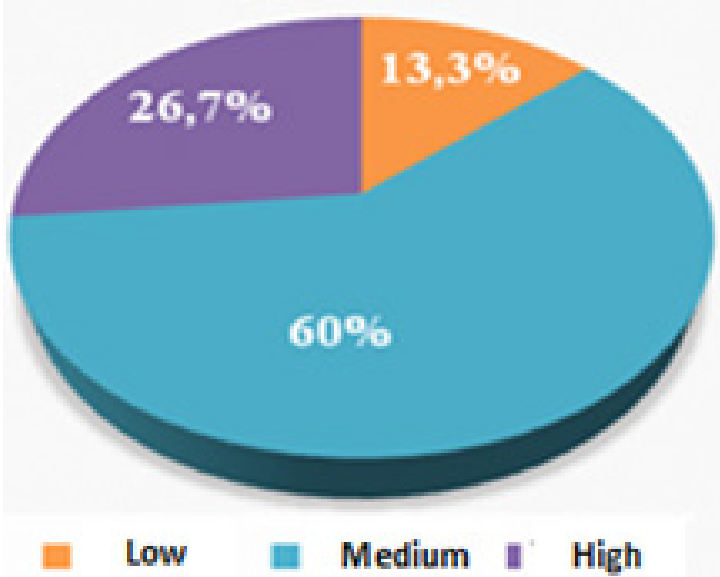

Figure 3. The Attitude of JMD in Banyumas Regency 2015
There are $26.7 \%$ of JMD who have unfavorable attitudes about malaria. Those unfavorable attitudes are demonstrated, especially in terms of understanding that malaria preventive measures which are carried out only if in the neighborhood has malaria patients (33.3\%), the tasks of JMD are just to create and deliver blood preparations to Puskesmas (53.3\%) and blood taking is only performed to the patients with fever (33.3\%).

4) JMD Skills

JMD skill consists of the activities of home visits, periodic reports submission, blood clots delivery, responsibility for the

Table 3. The attitude of JMD in Banyumas Regency

\begin{tabular}{|c|c|c|c|c|c|}
\hline No. & Statement & $\begin{array}{c}\text { Strongly } \\
\text { agree } \\
\mathrm{f}(\%)\end{array}$ & $\begin{array}{l}\text { Agree } \\
\mathrm{f}(\%)\end{array}$ & $\begin{array}{l}\text { Disagree } \\
\mathrm{f}(\%)\end{array}$ & $\begin{array}{c}\text { Strongly } \\
\text { Disagree } \\
\mathrm{f}(\%)\end{array}$ \\
\hline 1 & Malaria is a serious health problem & $\begin{array}{c}4 \\
(26,7)\end{array}$ & $\begin{array}{c}11 \\
(73,3)\end{array}$ & $\begin{array}{c}0 \\
(0)\end{array}$ & $\begin{array}{c}0 \\
(0)\end{array}$ \\
\hline 2 & $\begin{array}{l}\text { Patients with malaria must not worry because malaria can heal } \\
\text { itself }^{*}\end{array}$ & $\begin{array}{c}0 \\
(0)\end{array}$ & $\begin{array}{c}0 \\
(0)\end{array}$ & $11(73,3)$ & $\begin{array}{c}4 \\
(26,7)\end{array}$ \\
\hline 3 & $\begin{array}{l}\text { Malaria prevention just needs to be done when there is a case } \\
\text { found in the surrounding }\end{array}$ & $\begin{array}{c}0 \\
(0)\end{array}$ & $\begin{array}{c}5 \\
(33,3)\end{array}$ & $\begin{array}{c}8 \\
(53,3)\end{array}$ & $\begin{array}{c}2 \\
(13,3)\end{array}$ \\
\hline 4 & $\begin{array}{l}\text { We recommend that blood clots should be in good quality to } \\
\text { facilitate the examination of malaria }\end{array}$ & $\begin{array}{c}5 \\
(33,3)\end{array}$ & $10(66,7)$ & $\begin{array}{c}0 \\
(0)\end{array}$ & $\begin{array}{c}0 \\
(0)\end{array}$ \\
\hline 5 & $\begin{array}{l}\text { JMD should not be established in an area which is not malaria } \\
\text { endemic }\end{array}$ & $\begin{array}{c}0 \\
(0)\end{array}$ & $\begin{array}{c}9 \\
(60)\end{array}$ & $\begin{array}{c}5 \\
(33,3)\end{array}$ & $\begin{array}{c}1 \\
(6,7)\end{array}$ \\
\hline 6 & Blood taking should be done by JMD for the fever patients only* & $\begin{array}{c}0 \\
(0)\end{array}$ & $\begin{array}{c}5 \\
(33,3)\end{array}$ & $\begin{array}{c}10 \\
(66,7)\end{array}$ & $\begin{array}{c}0 \\
(0)\end{array}$ \\
\hline 7 & Home visit done by JMD is once a mont at the longest. & $\begin{array}{c}1 \\
(6,7)\end{array}$ & $\begin{array}{c}13 \\
(86,7)\end{array}$ & $\begin{array}{c}1 \\
(6,7)\end{array}$ & $\begin{array}{c}0 \\
(0)\end{array}$ \\
\hline 8 & $\begin{array}{l}\text { Educating socialization about malaria should not be done by } \\
\text { JMD }^{*}\end{array}$ & $\begin{array}{c}0 \\
(0)\end{array}$ & $\begin{array}{c}1 \\
(6,7)\end{array}$ & $\begin{array}{c}12 \\
(80)\end{array}$ & $\begin{array}{c}2 \\
(13,3)\end{array}$ \\
\hline 9 & $\begin{array}{l}\text { JMD tasks should be only to create and deliver blood preparation } \\
\text { to Puskesmas }\end{array}$ & $\begin{array}{c}0 \\
(0)\end{array}$ & $\begin{array}{c}8 \\
(53,3)\end{array}$ & $\begin{array}{c}7 \\
(46,7)\end{array}$ & $\begin{array}{c}0 \\
(0)\end{array}$ \\
\hline
\end{tabular}

Source: primary data

all the materials, equipment and medicines, preparation of blood that are qualified. Here is the further description of JMD skills.

The result show that JMD skill is still not good as shown by the process of preparation of blood which is not correct and the delivery of blood clots which is not done immediately. Not all JMD conduct home visits and make periodic reports.

The aspect of blood preparation is measured through observation. The observation of preparation skill for blood supply is done by asking JMD to practice the procedure which is commonly performed for blood clots. Researchers look at every stage and the procedures which are performed by JMD. If one does not administer the procedure correctly, the skill is categorized lacking/poor. The result shows the entire JMD (100\%) have not done the preparation of blood properly. The stages of preparation of blood which are still mistaken for example are by not shedding the blood for thinner blood, not shedding three drops for thick blood, object glass is not placed on a flat surface, not spreading the blood for thinner blood, not shifting the object glass 
Table 4. Distribution of JMD Skill in Banyumas Regency 2015

\begin{tabular}{llll}
\hline No. & \multicolumn{1}{c}{ Activities } & Total & $\begin{array}{c}\text { Percentage } \\
(\%)\end{array}$ \\
\hline 1. & Home Visit & & \\
& Yes & 14 & 93,3 \\
& No & 1 & 6,7 \\
\hline 2. & Periodic Report & & \\
& Yes & 13 & 86,7 \\
& No & 2 & 13,3 \\
\hline 3. & Immediate Blood & & \\
& clots delivery & 8 & 53,3 \\
& Yes & 7 & 46,7 \\
& No & & \\
\hline 4. & Responsibility & & \\
& Yes & 15 & 100,0 \\
& No & 0 & 0,0 \\
\hline 5. & Preparation of \\
& qualified blood & 0 & 0,0 \\
& Correct & 15 & 100,0 \\
$\quad$ Incorrect & & \\
\hline Source: primary data & &
\end{tabular}

by $45^{\circ}$ angles. Here is the further description on the results of observation on JMD blood preparation.

The average age of JMD in Banyumas regency is 48.4 years old. However, there are JMD who is 65 year old. This will affect their work performance. When JMDs are older, the chance of maturity and information being absorbed is also increased. But a person's physical ability is certainly a part that determines the quality of performance as well. One of the factors that determines a person's physical ability is age. The relationship between age and performance is very important. Although there is no strong evidence, but there is widespread belief that performance is decreased in accordance with age. Age is often the cause of the decline in mental and psychomotor performances. JMDs age is a factor that must be concerned so that maximum performance can be achieved. JMDs who are in their old age should be retired and replaced with someone who has a younger

Table 5. Description of JMD Skills on Blood Preparation in Banyumas Regency 2015

\begin{tabular}{llll}
\hline No. & Statement & True $\mathrm{f}(\%)$ & False $\mathrm{f}(\%)$ \\
\hline 1 & palms facing upwards & $15(100)$ & $0(0)$ \\
2 & middle finger or ring finger is selected & $15(100)$ & $0(0)$ \\
3 & Cleaning with alcohol swab & $14(93,3)$ & $1(6,7)$ \\
4 & fingers are pressed & $15(100)$ & $0(0)$ \\
5 & Fingertip is pricked & $15(100)$ & $0(0)$ \\
6 & First blood drop is cleaned using dry cotton & $13(86,7)$ & $2(13,3)$ \\
7 & Fingertip is pressed again & $14(93,3)$ & $1(6,7)$ \\
8 & Object glass is clean & $15(100)$ & $0(0)$ \\
9 & Object glass is held at the edge & $15(100)$ & $0(0)$ \\
10 & Finger position is under object glass & $12(80,0)$ & $3(20,0)$ \\
11 & Dropped one drop for thin blood at the center & $4(26,7)$ & $11(73,3)$ \\
12 & Dropped three drops thick blood at the edge & $6(40,0)$ & $9(60,0)$ \\
13 & Remaining blood is cleaned using cotton & $13(86,7)$ & $2(13,3)$ \\
14 & Object glass placed on the able or flat surface & $4(26,7)$ & $11(73,3)$ \\
15 & New object glass is placed until the blood is spreading for thin blood & $3(20,0)$ & $12(80,0)$ \\
16 & Object glass is shifted by 45 ${ }^{0}$ angle so the blood preparation & $3(20,0)$ & $12(80,0)$ \\
17 & Blood is made homogeny so circle is formed for thick blood & $15(100)$ & $0(0)$ \\
18 & No mistake is made for blood preparation & $10(66,7)$ & $5(33,3)$ \\
19 & Object glass gets label & $15(100)$ & $0(0)$ \\
20 & Drying process does not use light and hair dryer & $15(100)$ & $0(0)$ \\
21 & Blood is saved in safe place & $15(100)$ & $0(0)$ \\
\hline
\end{tabular}

Source: primary data 
age. In the education variable, it shows that most JMDs (73.3\%) in Banyumas Regency are included in the category of low education that graduated from elementary school and junior high school. Study or level of formal education can affect the quality of the work, the higher the education of JMD, the higher ability and skill in completing work tasks assigned to them (Yuniarti, 2012). High levels of education will make a good performance (Khayati, 2012). Therefore, several efforts for increasing JMD abilities and skills through training are necessary. Assisting and monitoring the performance of the JMD are also required.

All JMDs are in Banyumas Regency have another job. Therefore, it can be concluded that being JMDs is only their side job. They work primarily as peasants, workers, village officials, cooperative management and a kindergarten teacher. As for wage/salary, they receive Rp. $200,000.00$ per month and are only paid for 10 months in a year. JMD complain and feel that the amount of wages is lesser than the assignment burden. Overall income from main employment and as JMD is still relatively small; almost $90 \%$ of their income is below Rp. $1,100,000.00$. The results of the interview obtain information that at least the wages makes the lack of motivation as JMD.

Most JMD in Banyumas regency have worked as JMDs for 8.8 years. Although there is one person working for just 1 year and there are already 14 years. The result of research by Khayati (2012), states that the longer a person's working life, their skills will be better because they adjust to the job. With a lot of experience and adjustment, they gain more skills so that the quality of work performance will be better. A total of $93.3 \%$ JMDs report that they have never joined the training during the last 3 years. This result shows that the concern from related parties such as health agencies and health centers in malaria elimination efforts is lacking. JMDs are indeed frontier troops in eradicating malaria cases actively. The trainings were conducted in 2008. The continuous training of health cadres is needed to improve their knowledge and skills (Kalyango, 2012).

The results show there is still a third JMDs in Banyumas who are included in less knowledgeable. Besides low education levels, lack of training is to be blamed for their lack of knowledge. There are also some JMDs who are elders. The poorly understood aspects of knowledge JMDs including on the definition, etiology, transmission, symptoms and drying processes in creating of blood preparation, although some may already know. This shows that they still need to improve their knowledge through training and mentoring. Knowledge aspects which JMDs do not know the most are for example about malaria symptoms of nausea and plasmodium falciparum causes severe malaria. They give wrong answer $73.3 \%$ and $60,0 \%$ respectively.

JMDs in Banyumas Regency complain that training activities for them is rarely carried out by Puskesmas and district health office. It is supposed to influence the knowledge and skills JMDs. Training activities is essentially a series of activities designed to improve the skills, knowledge, experience or changes in attitudes and skills to carry out the current and future work better. According to Liliweri (2007), in general, the broad scope or insight knowledge of a person is determined by the person's level of education. The increasing levels of education will mostly determine the tendency to understand something better. Educational background of someone influences their learning process. Learning process is also influenced by psychological conditions such as the intelligence, comprehension, memory and motivation. Education can affect a person including their behavior which becomes the pattern of life, especially in the attitude to participate in the education for obtaining the information. The results of questionnaires that have been processed show that there are some items in the questionnaire which are answered incorrectly by JMDs such as the causes of severe malaria, the main symptoms of malaria, malaria prevention, drying and painting of blood clots.

The results show that $26.7 \%$ JMDs in Banyumas have an attitude about malaria which is still not good. Attitude is influenced by several things including personal experiences, cultures of others that are considered important by the mass media, institutions or educational institutions and religious institutions as well as the emotions of the self or the individual. Attitude is not brought people from birth, 
but is formed throughout their development. Attitudes can change, therefore it is learned. Attitude cannot stand alone and is always associated with an object. Attitude is a reaction or response which is still closed from a person to a stimulus or object. Attitude is not an action or behavior.

The attitude of JMDs in Banyumas regency is still not good, especially in understanding the preventive measures of malaria which they think should be performed only when there is malaria patient in their surrounding environment. They also think that the task of JMDs is just to create and send blood clots to Puskesmas and prepare blood clots only in patients with fever. Malaria precautions should be done at any time without having to wait new patients; this should be understood by JMDs and society. In regard to JMDs task, in addition to creating and sending blood clots to the clinic, JMDs must provide counseling and mentoring to take medication the patient and to promote the preventive efforts of malaria. JMDs also do not have good attitude because they only take the blood in patients with fever, to areas endemic areas, malaria symptoms had been asymptomatic. Therefore if there is a suspected are with high risk of malaria, blood collection should be done immediately.

Answers from the questionnaires and observations about JMDs in Banyumas obtain information that all are in the category of less good. An attitude is not necessarily manifested in action. JMDs might answer questions with correct answers, but the attitude JMDs is not always realized in real action. Attitude is always associated with behaviors that are within the boundaries of normality for particular response or reaction to stimulus. Attitude is essentially just a predisposition or tendency to behave, so it cannot be said to be an activity or action. This is in accordance with the opinion that the attitude is a form of evaluation or reaction to an object. So, although the attitude of JMD is mostly good, but it is not necessarily in line with the behavior/practice.

The results of the questionnaires and observation show that the JMDs skills are still lacking, particularly in terms of practice of blood preparation. JMDs in Banyumas Regency have been performing the procedure of making blood clots in accordance with the guidelines, but most of them do not do the preparation of blood thinner. Although there are some of them who do, they still make mistakes. Therefore, the preparation of the blood is not in accordance with procedures.

The preparations blood thinner is used to determine the type and phase of the parasite and the type of drug to be administered to patients with malaria. Erythrocytes in thin blood clots should be intact, so the shape and morphology of the parasite is still perfect. The structure of the parasite in thin blood clots are seen more clearly so the plasmodium species and stage (phase) is easier to identify. This theory makes the importance of preparation of a blood thinner for the diagnosis of malaria is accurate. This is the first step in providing proper and quick treatment so that complications can be avoided. $60 \%$ of the preparation of blood performed by JMD in Banyumas Regency has not met the qualifications. The mistakes that occur are generally when the creation of thin blood is not shaped like tongue, greasy or dirty, whereas for thick blood clots are unevenly thick.

The mistakes during preparation of a thick blood and most of them do not perform procedures to shed as much as over 3 drops of thick blood clots. According to the Technical Guidelines for Malaria Parasite checks if the amount of blood used too much will cause the malaria parasite difficult to see. Moreover, error occurs when the blood homogenize, glass objects are not placed on a table or flat surface so that the thickness is not even. The mistakes during preparation of a blood thinner that is the object glass is not shifted by $45^{\circ}$ angle quickly in the opposite direction with drops of whole thick blood. This shows that the procedure of thick and thin blood preparation by JMD in Banyumas is not yet qualified.

The quality of blood clots, determination of indications targeted by JMD, activities of home visits and distribution of the population by JMD can affect the level Slide Positivity Rate (SPR) for the discovery of cases of malaria. Monitoring and evaluation of the quality of blood clots is required in order to realize malaria elimination. It is also important that diagnostic method must implement Rapid 
Diagnostic Test (RDT). RDT method is easier and more practical if it is used for areas that are difficult to be reached and the current outbreak areas. The results of research in Africa, Zambia and three other African countries (Uganda, Burkina Faso and Ghana) shows the use of RDT by a cadre of more safe and effective malaria (Mubi, 2011, Harvey 2008, Mukanga, 2012). In Senegal, the cadres of malaria implement home-based management with RDT diagnostic and therapeutic combinations in reduction in the incidence of malaria and deaths in hospitals amounted to $62.5 \%$ (Thiam, 2012).

The results of observations about the practices of JMDs show that there are still JMDs who do not have home visit schedule, do not make periodic reports and do not send blood clots immediately. Home visit schedule that has been created by JMDs will increase coverage of Active Case Detection (ADC). This activity aims to find malaria early, provide treatment as quickly as possible, watch the fluctuations in malaria cases and outbreaks as early warning. Therefore, JMDs are expected to perform the activity of at least one month at the latest. Making periodic reports to the malaria program manager of the health center aims to monitor developments in the case malaria in Puskesmas area. Non-performance of the reporting period would hinder monitoring fluctuations so that outbreaks of malaria cases cannot be prevented as early as possible.

\section{Conclusion}

Based on the results, information about the level of existing knowledge, attitudes and skills of JMDs towards malaria elimination in Banyumas is still considered lacking. Aspects of knowledge is still lacking, especially in the definition, etiology, transmission, symptoms and drying processes in the manufacture of blood clots. Aspects attitude is lacking, especially in understanding the task JMDs which they think only to create and submit blood clots, blood sampling is only performed for patients with fever and the only prevention is only done when there is malaria cases appear in their surrounding environment. The skill aspect which is stil lacking is in the procedure of preparation of blood. JMDs need more training to develop their skills in aspects of knowledge, attitudes and skills so that detection and treatment of malaria can be accurately and malaria elimination can be achieved.

\section{References}

Badan Penelitian dan Pengembangan Kesehatan Kemenkes RI. 2013.Riset Kesehatan Dasar.

Elyazar, I. R. F., et al. (2011). Plasmodium falciparum Malaria Endemicity in Indonesia in 2010. PLoS ONE, 6(6), e21315.

Harvey, S. et al. (2008). Improving Community Health Worker Use of Malaria Rapid Diagnostic Tests in Zambia: Package Instructions, Job Aid and Job Aid-PlusTraining. Malaria Journal, 7(group 1), 160. doi:10.1186/1475-2875-7-160

Kalyango, J. N., Ret al. (2012). Performance of Community Health Workers Under Integrated Community Case Management of Childhood Illnesses in Eastern Uganda. Malaria Journal, 11, 282. doi:10.1186/14752875-11-282 [doi]

Khayati, N, Yuliawati, S, Arie, M.W. 2012. Beberapa Faktor Petugas yang Berhubungan dengan Pelaksanaan Surveilans Epidemiologi Malaria Tingkat Puskesmas di Kabupaten Purworejo. Jurnal Kesehatan Masyarakat (2) :364-373.

Liliweri, A. 2007. Dasar-Dasar Komunikasi Kesehatan. Pustaka Pelajar: Yogyakarta.

Mubi, M., et al. (2011). Malaria Rapid Testing by Community Health Workers Is Effective and Safe for Targeting Malaria Treatment: Randomised Cross-Over Trial in Tanzania. PLoS ONE, 6(7), e19753.

Mukanga, D., et al. (2012). Integrated Community Case Management of Fever in Children under Five Using Rapid Diagnostic Tests and Respiratory Rate Counting: A Multi-Country Cluster Randomized Trial. American Journal of Tropical Medicine and Hygiene, 87(Suppl 5), 21-29.

Rejeki, D. S. S., Sari, R. A., \& Nurhayati, N. (2014). Annual Parasite Incidence Malaria di Kabupaten Banyumas. Kesmas (Jurnal Kesehatan Masyarakat Nasional), 9(2) :137143.

Renwarin, V. M. V, \& Kandou, J. M. L. U. G. D. (2014). Analisis Pelaksanaan Program Eliminasi Malaria di Kota Tomohon Analysis Implementation of Malaria Elimination Program in Tomohon. JIKMU, Suplemen, 4(4), 634-643.

Thiam, S., et al. (2012). Scale-Up of Home-Based Management of Malaria Based on Rapid Diagnostic Tests and Artemisinin-Based 
Combination Therapy in a Resource-Poor Country: Results in Senegal. Malaria Journal, 11(1), 334.

Yuniarti, Zahroh S., Bagoes W,. 2012. Kinerja
Petugas Penyuluh Kesehatan Masyarakat dalam Praktek Promosi Kesehatan di Dinas Kesehatan Kabupaten Pati. Jurnal Promosi Kesehatan Indonesia (7) : 165-173. 